\title{
Partnerships and Extension: Evidence from India
}

\author{
K. Narendran \\ Indian Institute of Plantation Management, Jnana Bharathi Campus, Bengaluru India \\ Corresponding author email: agrinarenk@gmail.com
}

\section{ABSTRACT}

Partnerships between the government, private players, and farmers are essential for agri-business in agricultural nations such as India. However, the farming community lacks awareness of and interest in entrepreneurship or partnerships. This study evaluates various approaches to promote farmer participation in agri-PPPs (public-private partnerships).A multistage and purposive sampling technique was employed. Nine agricultural produce marketing committee (APMC) markets in Karnataka, India, were randomly chosen to understand the PPP model's functioning in operating and maintaining cleaning and grading facilities. Of the total 180 respondents, 20 of each APMC were officials, traders, and farmers. Analysis of variance (ANOVA) and Duncan's method were applied to test each party's interest in PPPs. The fixed revenue-sharing model is the most suitable as the government bears the capital costs, while the private partner oversees operations. The proportionate revenue-sharing model is ideal for the private sector, which undertakes design, development, and operations, with limited government intervention. The ANOVA test indicated a significant difference in awareness and interest among farmers, traders, and officers. Further, a post hoc analysis with the Duncan method showed that the farmers having low awareness of and interest in PPPs.

KEY WORDS: PARTICIPATION; PUBLIC-PRIVATE PARTNERSHIP; ENTREPRENEURSHIP APPROACH; EXTENSION; REVENUE SHARING.

\section{INTRODUCTION}

Rural progress in developing countries such as India hinges on the growth of agribusinesses. Both institutions and governments consider community entrepreneurship as a strategic growth channel to accelerate the development process. Farmers see such entrepreneurship as an opportunity to earn improved profits, while women view it as an opportunity to apply their time and skills to attend to family responsibilities; finally, such entrepreneurship also widens the scope for youth to gain employment and earn a livelihood. Community entrepreneurship aims to advance the agricultural profession by improving product quality, the livelihood of farming households, and consumers' well-being, as well as sustaining a clean economy and green environment.

Conventionally, India's extension strategy has primarily focused on transferring information or ensuring the

Biosc Biotech Res Comm P-ISSN: 0974-6455 E-ISSN: 2321-4007

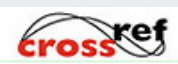

Identifiers and Pagination

Year: 2021 Vol: 14 No (5) Special Issue

Pages: $265-269$

This is an open access article under Creative

Commons License Attribn 4.0 Intl (CC-BY).

DOI: $h t t p: / / d x$.doi.org/10.21786/bbrc/14.5/48 diffusion of innovation, to help people develop. Extension approaches focus more on indirect mechanisms such as acquiring new knowledge and developing new skills, rather than on bringing about a direct change. However, extension professionals must play a facilitator's role and guide people to make changes in their families, businesses, farms, or communities. Extension outcomes need to be real, enabling meaningful changes in people's livelihoods, and not just focus on knowledge acquisition.

The term 'entrepreneurship approach 'refers to helping farmers and their communities by providing sustainable livelihood and income through rural business creation. This approach promotes business based on local resources, marketing needs, or the product's value chain. Entrepreneurs must focus on the value chain of different commodities, including the supply of inputs, production, processing, value addition, cold chain, distribution, and improved market access. Primary processing creates entrepreneurial opportunities with an aim to satisfy consumer preferences, as well as ensure food safety, traceability, and quality. Accordingly, it is important to have infrastructure at various levels of the agricultural value chain to promote entrepreneurship in rural areas.

Participation In Partnership (P-I-P): Ensuring a high level of involvement is critical. Traditionally, various

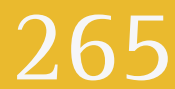


participation channels have been employed to ensure people's involvement - either active or passive in development processes. The participation ladder describes how people can steadily change from being passive spectators (beneficiaries) to key actors (agents of self-development). This involves a transition from 'Participation' to 'Partnership'. Public-private partnerships (PPPs) may be suitable tools for developing and managing agricultural infrastructure, as they encompass a wide range of possible associations between the public and private sectors for rural development and livelihoods. Entrepreneurs, non-governmental organisations, and farmer organisations such as farmer producer organisations (FPOs), could be considered at par with private players in this context. FAO (2016) defined an agri-PPP as a 'formalised partnership between public institutions and private partners designed to address sustainable agricultural development, where the public and private players share the benefit and the risk'. Cui et al. (2018) observed that the PPP approach was originally adopted to enhance.

According to Van den Hurk (2018), the PPP model for infrastructure can benefit both the private and public sectors. FAO (2016) found value-chain PPPs at the meso and micro levels worldwide. In meso-level agri-PPPs, the public sector plays a prominent role in facilitating, coordinating, and supporting small farmers. The private partner controls all business activities, with limited interference from the public partners. Either a partner or a third party may offer extension service such as skill development and training. Shukla, Sharma, and Thumar (2016) suggested that establishing agricultural infrastructure at different agricultural chain levels is key to vibrant and competitive agriculture. PPPs could be a useful tool to accelerate development in various areas of agribusiness and infrastructure. The WEF and McKinsey (2013) observed that agri-PPPs could modernise the agriculture sector and deliver multiple benefits that can contribute to the pursuit of sustainable agricultural development, including among smallholding farmers.

Ponnusamy (2013) indicated that PPPs are among the best proven strategies for achieving specific goals within a time frame, particularly for modernising public services, developing agricultural infrastructure, and offering extension services. Reasons for the evolution of PPPs in various fields include the lack of facilities, human resources, and time. The different forms of PPP-such as service contracts, management contracts, leases, concessions-and their differentiation based on ownership, operations, maintenance, capital investment, commercial risk-bearing, and contract duration, are listed in Table 1. Appropriate models may be selected based on the business plan, period, and type of service provided to the farming community. Under field conditions, agriPPPs may follow either contractual or collaborative measures, and lean towards primary, limited contract modalities such as memoranda of understanding, compared to traditional PPPs for infrastructure.

\begin{tabular}{|c|c|c|c|c|c|}
\hline Option & $\begin{array}{c}\text { Asset } \\
\text { Ownership }\end{array}$ & 0 \&t M & $\begin{array}{c}\text { Capital } \\
\text { Investment }\end{array}$ & $\begin{array}{l}\text { Demand } \\
\text { Risk }\end{array}$ & $\begin{array}{c}\text { Duration } \\
\text { (Years) }\end{array}$ \\
\hline $\begin{array}{l}\text { Service } \\
\text { Contracts }\end{array}$ & Government & $\begin{array}{l}\text { Government } \\
\text { and private }\end{array}$ & Government & Government & $1-2$ \\
\hline Management Contracts & Government & Private & Government & Government & $3-5$ \\
\hline Lease & Government & Private & Government & Shared & $8-15$ \\
\hline Concessions & Government & Private & Private & Private & $20-30$ \\
\hline B00T/B00 & $\begin{array}{l}\text { Private and } \\
\text { Government }\end{array}$ & Private & Private & Private & $20-30$ \\
\hline (Source: FA0, 2016) & & & & & \\
\hline
\end{tabular}

Figure 1: Proportionate Revenue Share (PRS) Model

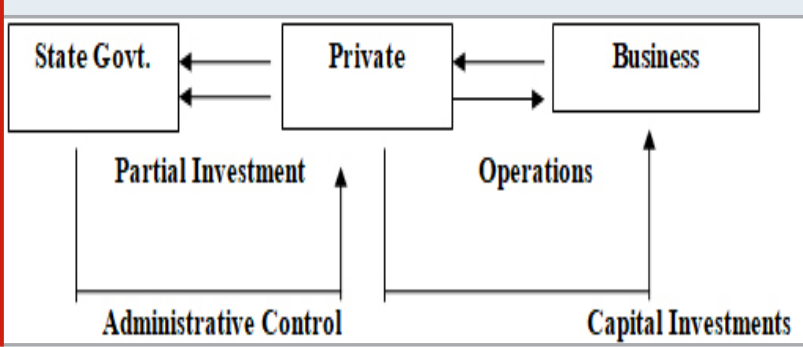

MATERIAL AND METHODS

India is geographically divided into the southern, northern, eastern, and western regions. Multistage
Figure 2: Fixed Revenue Share (FRS) Model

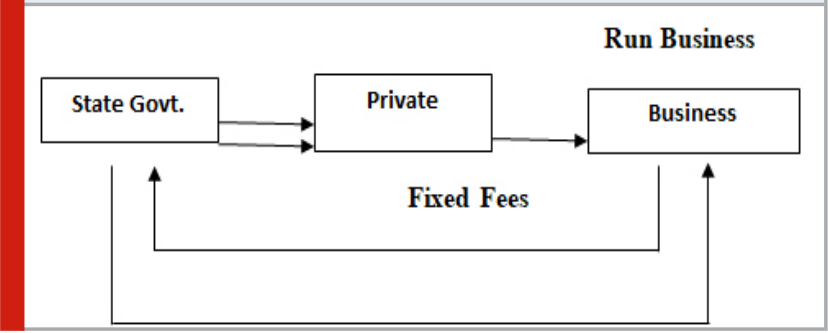

and purposive sampling techniques were used in this study. The southern state of Karnataka was chosen as the research setting, owing to its success in implementing PPPs for agricultural infrastructure. 
The state has approximately 150 district agricultural produce marketing committee (APMC) markets. The state marketing department selected 50 APMCs based on the feasibility of establishing cleaning and grading units in these APMCs. Finally, nine APMCs were randomly chosen to understand the functioning of the PPP model. Of the total 180 respondents, 20 were randomly selected from officials (4), traders (8), and farmers (8) in each APMC. A three-point scale response -'strongly agree', 'agree', and 'disagree' was used to capture the responses. Analysis of variance (ANOVA) and Duncan's method were applied to statistically compare the interest of officials (public), traders and entrepreneurs (private), and farmers (people) in the partnerships.

Table 2. ANOVA The relationship between PPP and farmers, traders, and officers

\begin{tabular}{|l|c|l|l|l|l|l|l|l|}
\hline Groups & $\mathrm{N}$ & Mean & $\begin{array}{c}\text { Std. } \\
\text { Deviation }\end{array}$ & $\begin{array}{c}\text { Std. } \\
\text { Error }\end{array}$ & \multicolumn{2}{|c|}{$\begin{array}{c}\text { 95\% Confidence } \\
\text { Interval for Mean }\end{array}$} & Minimum & Maximum \\
\hline & & & & & $\begin{array}{c}\text { Lower } \\
\text { Bound }\end{array}$ & $\begin{array}{c}\text { Upper } \\
\text { Bound }\end{array}$ & & \\
\hline Farmers & 72 & 1.58 & .190 & .085 & 1.35 & 1.82 & 1 & 2 \\
\hline Traders & 72 & 2.47 & .156 & .070 & 2.27 & 2.66 & 2 & 3 \\
\hline Officers & 36 & 2.02 & .968 & .433 & .82 & 3.22 & 1 & 3 \\
\hline Total & 180 & 2.02 & .651 & .168 & 1.66 & 2.38 & 1 & 3 \\
\hline
\end{tabular}

\begin{tabular}{|l|c|c|c|c|c|}
\hline Groups & Sum of Squares & df & Mean Square & F & Sig. \\
\hline Between Groups & 1.945 & 2 & .972 & 2.926 & .092 \\
\hline Within Groups & 3.989 & 12 & .332 & & \\
\hline Total & 5.934 & 14 & & & \\
\hline
\end{tabular}

Table 3. Duncan test for inter-group difference

\begin{tabular}{|l|c|c|c|c|}
\hline & & & \multicolumn{3}{|c|}{ Groups } & $\mathrm{N}$ & $\mathrm{df}$ & \multicolumn{2}{|c|}{ Subset for alpha $=0.05$} \\
\hline & & & 1 & 2 \\
\hline Farmers & 72 & 2 & 1.58 & \\
\hline Traders & 72 & 12 & & 2.02 \\
\hline Officers & 36 & 14 & & 2.47 \\
\hline Significance & & & & .245 \\
\hline
\end{tabular}

Means for groups in homogeneous subsets are displayed.

\section{RESULTS AND DISCUSSION}

The partnership process must be broad and results oriented. The new system of governance and policy in India expects more accountability and transparency, even in the public sector. To ensure a strong return on the government's resource investment as well as efficiency in the private sector, it is essential to establish a strong partnership that would reduce unnecessary expenditure and facilitate delivery in the public sector. These PPP models follow a win-win strategy to share risks and returns equally. The public sector must be ready to reduce its complete ownership of projects and share the expected revenue with the private partner. The private partner, on its part, should actively contribute to better delivery and results.

A PPP involves sharing capital, working capital, revenue,
Figure 3: Plan for Entrepreneurship Approaches

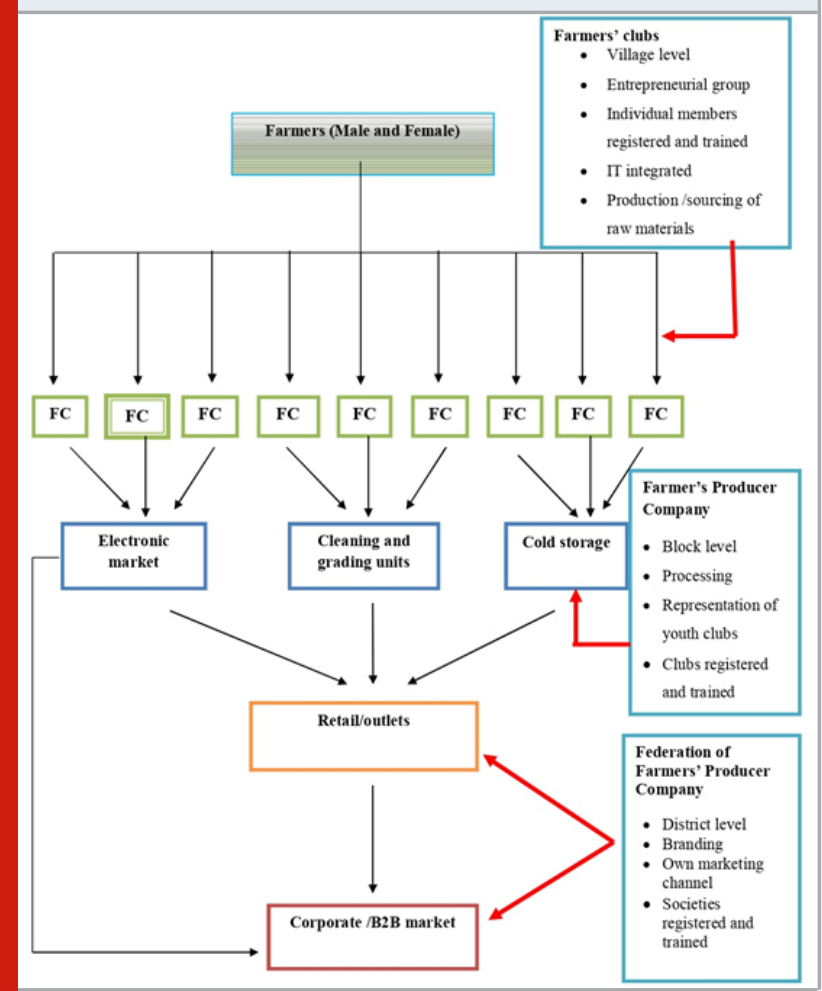

risk, responsibility, assets, and authority. The marketing department considers the PPP's principles and after a detailed deliberation, identifies a fixed revenue-sharing (FRS) model. As shown in Figure 1, this model is based on 
infrastructure development through capital investment by the public sector and the business function of the private partner. The FRS model suits public players when the government lacks human resources or expertise, or when the project involves social responsibility. The marketing department conclude that to provide the best possible service to the farming community, the government should provide financing, while the private sector manages the business competently.

Further, when the department proposes to start new markets on highways, it requires the private sector to play a dominant role in investment and operations. Here, the proportionate revenue-sharing (PRS) model is preferred. As shown in Figure 2, this model depends on the private partner's capacity to play a significant role in several activities, including sourcing land, financing, and managing independently. The government may finance infrastructure to a maximum of one-fourth of the project's cost. Effective monitoring and assessment guidelines are essential for the model's execution.

PPP is a mutual contract between a public and a private entity to optimise resources, expertise, and functions, to benefit the farming community (Anonymous, 2011). The respondents were asked about their level of agreement with the need for PPPs as well as the revenue-sharing model. The 180 respondents consisted of 36 officials, 72 traders/entrepreneurs, and 72 farmers. The importance of PPP's and farmers, traders, and officers is shown in Table 2. The table indicates a significant difference (0.092) among farmers, traders, and officers.

Post-hoc analysis was conducted using the Duncan method to understand the inter-group differences regarding PPPs. Table 3 are based on each group's interest in PPPs. The mean value for farmers was 1.58 . Traders and officers were grouped separately with mean values of 2.47 and 2.02, respectively. The difference in mean values between farmers and officers/traders was significant (.245). This means that farmers have a low level of awareness of and interest in PPPs. Most of the APMC officials and traders preferred PPP's. However, farmers showed low interest in them. The study identified certain factors that were crucial to ensuring participation in PPP's. The follow-up discussion revealed that the authorities offered many concessions to farmers and women while selecting private players to maintain the cleaning and grading units, and that PPPs functioned successfully in relation to the operation and maintenance of the cleaning and grading units. As Alfen et al. (2009) state PPP has become a common procurement strategy in developed and developing countries.

Further, less than $10 \%$ of farmers use the facility despite having to pay only minimal cleaning and grading charges. This clearly shows the need for an extension intervention to create interest in and motivation for these partnerships. IFAD (2013) states that the FEDEC project enhanced the partnership level of micro-entrepreneurs through training in the selected value chains. According to the FAO (2016), Indonesia's palm oil case study highlights the essential role of farmer organisations or cooperatives at all stages of the partnership. The term public - private-producer partnership (4P) has recently emerged, highlighting the integral part that producer organisations can play in PPP projects. The term has been adopted in several developed countries such as Canada (VALGEN, 2012; OECD, 2014; Syngenta, 2014), to acknowledge producer organisations' contribution to coordinating and co-financing PPP activities through the fees collected.

These results emphasise that the extension system must facilitate an entrepreneurial orientation through training, workshops, and incubators. As shown in Figure 3, the entrepreneurship approach connects different stakeholders in the chain. Farmers (men and women) form clubs at the village level. Clubs combine to form farmers' producer companies, and become a part of PPP to better utilise agricultural infrastructure (e.g., e-marketing, cleaning, and grading/cold storage). Farmer's producer companies have to unite and form a federation for branding and marketing. The extension system must facilitate farmers' development at the micro, meso, and macro levels and strengthen PPPs.

\section{CONCLUSION}

Agribusiness partnerships must consider different partners' strengths and areas of expertise to meet the farming community's requirements. Public partner must have a clear rationale for promoting PPPs, monitoring mechanisms, and a private party role. Potential PPP projects should establish value-for-money, and ideally generate more significant results than traditional program mechanisms. Effective agri-PPPs share risks fairly among partners and include risk-management mechanisms to guard the most vulnerable stakeholders. Many agri-projects implemented by the public sector lack operational and business orientations.

Similarly, private businesses are not well connected to farmers. Therefore, agri-PPP agreements should facilitate a symbiotic relationship between the public and private partners to benefit both the producer and the consumer. As PPPs are the future, transparency and fairness must be ensured to achieve a better outcome. A legally binding document must be developed and utilised for smooth functioning. These documents could specify the roles and responsibilities of both partners and users. Agri-PPPs should ensure the participation of growers, youth, women, and FPOs as private partners for better implementation. Finally, the revenue-sharing approach brings about business orientation among major stakeholders. We should ensure more participation of farmers, producer companies, youth, women, and weaker sections of the society in the agri-PPP.

\section{REFERENCES}

Alfen Hans Wilhelm , Satyanarayana N. Kalidindi, Stephen Ogunlana, ShouQing Wang, Martinus P. Abednego, Andrea Frank-Jungbecker, Yu-Chien Amber Jan, Yongjian Ke, YuWen Liu, L. Boeing Singh, GuoFu 
Zhao. 2009. Public -Private Partnership in Infrastructure Development: Case Studies from Asia and Europe. Weimar:Bauhaus-Universität. http://nbnresolving.de/ urn:nbn:de:gbv:27-20100922-160114-1

Anonymous. 2011. Public-Private Partnership in Agricultural Marketing - A Case of Pune District, Maharashtra, 6-18. Jaipur, India: National Institute of Agricultural Marketing (NIAM).

Cui,Caiyun, Yong Liu, Alex Hope, and Jianping Wang. 2018. "Review of Studies on the Public-Private Partnerships (PPP) for Infrastructure Projects.”International Journal of Project Management 35(5): 773-794.https://doi. org/10.1016/j.ijproman.2018.03.004

Dhameja, Nand. 2017. "Public-Private Partnership for Infrastructure Development: Cross-Country Scenario."Indian Journal of Public Administration 54 (1): 21-33. doi:10.1177/0019556120080102

FA0. 2016. "Public-private partnerships for agribusiness development. A review of international experiences." www.fao.org/3/a-i5699e.pdf

IFAD. 2013. IFAD and Public-Private Partnerships: Selected Project Experiences. International Fund for Agricultural Development. Rome.

OECD. 2014. Public-private partnerships for agricultural innovation: 6th meeting of the Food Chain Analysis Network, 13-14 October 2014. Paris, Organisation for
Economic Co-operation and Development (OECD). http://www.oecd.org/site/ agrfcn/Agenda_PPP\%20 meeting_13-14\%200ctober\%202014\%20FINAL.pdf (accessed February 2016)

Ponnusamy, Kuppusamy. 2013. "Impact of Publicprivate Partnership in Agriculture: A Review.” Indian Journal of Agricultural Sciences 83 (8): 803-808.

WEF and McKinsey and Company. 2013. Achieving the New Vision for Agriculture: New Models for Action. Geneva: World Economic Forum.

Shukla, Ruchira, Swati Sharma, and V.M.Thumar. 2016. "Role and Importance of Public-Private Partnerships in Agricultural Value Chain and Infrastructure." International Journal of Commerce and Business Management 9 (1): 113-118. doi: 10.15740/HAS/ IJCBM/9.1/113-118

Syngenta. 2014. Syngenta part of innovative public, private, producer partnership (P4) to improve wheat breeding through double-haploid technology. Guelph, Ontario, Canada. (press release 7 October 2014). http:// www.farms.com/news/innovativeinitiative-accelerateswheat-breeding-82546.aspx (accessed February 2016) Van den Hurk, Martijn and Matti Siemiatycki. 2018. "Public-Private Partnerships and the Design Process: Consequences for Architects and City Building. International Journal of Urban and Regional Research. https://doi.org/10.1111/1468-2427.12629 